\title{
Effect of Training System and Fruit Load on Seed Production and Quality of Bell Pepper
}

\author{
Rohit Chandi $^{1 *}$, Rajender Sharma ${ }^{1}$ and Y. R. Shukla ${ }^{2}$ \\ ${ }^{1}$ Department of Seed Science and Technology, ${ }^{2}$ Department of Vegetable Science, \\ Dr. Y S Parmar University of Horticulture and Forestry, Nauni, Solan-173230, \\ Himachal Pradesh, India \\ *Corresponding author
}

\begin{abstract}
A B S T R A C T
\section{Keywords}

Training system, Fruit load and Electrical conductivity of seed

Article Info

Accepted:

20 June 2020

Available Online:

10 July 2020

Study was conducted on effect of training system and fruit load on seed production and quality of bell pepper using cv. "Solan Bharpur" in the Department of Seed Science and Technology, Dr. Y S Parmar University of Horticulture and Forestry, Nauni, Solan (HP) during kharif season 2018. The experiment was laid out in Randomized Block Design (Factorial) in the open field and in Completely Randomized Design (Factorial) in laboratory. Three training systems (no training $-\mathrm{Tr}_{1}$, two stem training $-\mathrm{Tr}_{2}$, four stem training $-\mathrm{Tr}_{3}$ ) and four fruit loads (retaining all fruits $-\mathrm{FL}_{1}$, retaining ten fruits $-\mathrm{FL}_{2}$, retaining twelve fruits $-\mathrm{FL}_{3}$, retaining fourteen fruits $-\mathrm{FL}_{4}$ plant $^{-1}$ ) were used with different treatment combinations. The treatment combination $\mathrm{Tr}_{2} \mathrm{FL}_{2}$ (two stem training with ten fruits plant ${ }^{-1}$ ) proved superior in terms of ripe fruit weight $(66.65 \mathrm{~g})$, ripe fruit length $(6.56$ $\mathrm{cm})$, ripe fruit width $(5.05 \mathrm{~cm})$, number of seeds fruit ${ }^{-1}(187.77), 1000$ seed weight $(6.21$ g), germination $(96.50 \%)$, speed of germination (15.95), seed vigour index-I (1448.30), seed vigour index-II (284.77) and electrical conductivity of seeds $\left(0.060 \mathrm{dSm}^{-1}\right)$. Therefore, $\mathrm{Tr}_{2} \mathrm{FL}_{2}$ treatment combination can be recommended for quality seed production of bell pepper under mid hills of Himachal Pradesh.
\end{abstract}

\section{Introduction}

Bell pepper (Capsicum annuum L. var. grossum Sendt) and chilli (Capsicum annuum L. var. longum) are very important vegetable fruit crops cultivated for their edible botanical fruit. Both of these crops are members of the family Solanaceae. Capsicum annuum L. var. grossum Sendt is a native of Mexico with secondary centre of origin in Guatemala (5). Britishers introduced it in $19^{\text {th }}$ Century in
Shimla, Himachal Pradesh and Nilgiri hills of Tamil Nadu (7). In India, capsicum is known by the name Shimla mirch, especially in northern regions. Other names of capsicum are sweet pepper, bell pepper, bull nose or capsicum. Himachal Pradesh is a leading supplier of bell pepper fruits to the plains during summer and rainy seasons, hence good source of fetching a higher price due to offseason cultivation. 
Seed is the basic input of agriculture and quality seed has been reported to improve yield by 10-20 per cent. Under Indian conditions, non availability of quality seed is the major constraint leading to low productivity. It is well said in manusmirti that "good seed on good land yields abundance produce". Green revolution in India was possible only due to quality seeds. The response of other inputs like irrigation, fertilizers depends on the quality of seed.

Two-stem training system in capsicum has been found best for most traits except, number of flowers plant ${ }^{-1}$ and days to first picking which were best under control i.e. on plants not trained at all (19). According to Ansari, 2012 (2) double stem training system can be recommended for commercial seed production of tomato. In bell pepper, studies by Thakur et al., 2018 (21) revealed maximum fruit weight $(175.91 \mathrm{~g})$ and least number of days to first harvest (89.36 days), early flower initiation as well as 50 per cent flowering (52.71 days) under two shoots training level. Planting density of $45 \times 30 \mathrm{~cm}$ in combination with two shoot training system can be recommended for commercial seed production of bell pepper (8). Nabi et al., 2009 (14) observed that retaining $1^{\text {st }}$ six fruits plant $^{-1}$ in capsicum increased per cent seed germination, 1000-seed weight and seedling vigour indices (both I and II). Maboko et al., (2012) (11) investigated that effect of plant population, flower and stem pruning of hydroponically grown peppers and concluded that quality can be effectively manipulated by plant population and stem pruning, while flower pruning had insignificant $(p<0.05)$ effect.

\section{Materials and Methods}

The experiment was laid down on $1^{\text {st }}$ May 2018 at Pandah Experimental Farm of the Department of Seed Science and Technology,
Dr. Y.S. Parmar University of Horticulture and Forestry, Nauni, Solan (HP) located at an altitude of $1250 \mathrm{~m}$ above mean sea level with latitude of $35.50^{\circ} \mathrm{N}$ and longitude of $77.80^{\circ} \mathrm{E}$ in the mid-hill zone of Himachal Pradesh (India). Bell pepper cv. Solan Bharpur seedlings were transplanted in a Randomized Block Design (Factorial) comprising of twelve treatment combinations replicated thrice. The seeds harvested were tested for quality parameters in laboratory using Completely Randomized Design (factorial) with the same set of treatment combinations replicated four times. Different combinations of training systems and fruit load $\left(\operatorname{Tr}_{1} \mathrm{FL}_{1}-\mathrm{No}\right.$ training and all fruits retained, $\operatorname{Tr}_{1} \mathrm{FL}_{2}-\mathrm{No}$ training and 10 fruits retained plant ${ }^{-1}, \mathrm{Tr}_{1} \mathrm{FL}_{3}-$ No training and 12 fruits retained plant $^{-1}$, $\mathrm{Tr}_{1} \mathrm{FL}_{4}-\mathrm{No}_{0}$ training and 14 fruits retained plant $^{-1}, \operatorname{Tr}_{2} \mathrm{FL}_{1}$-Two shoot training and all fruits, $\operatorname{Tr}_{2} \mathrm{FL}_{2}$-Two shoot training and 10 fruits retained plant ${ }^{-1}, \mathrm{Tr}_{2} \mathrm{FL}_{3}$-Two shoot training and 12 fruits retained plant ${ }^{-1}, \mathrm{Tr}_{2} \mathrm{FL}_{4}{ }^{-}$ Two shoot training and 14 fruits retained plant ${ }^{-1}, \operatorname{Tr}_{3} \mathrm{FL}_{1}$-Four shoot training and all fruits, $\operatorname{Tr}_{3} \mathrm{FL}_{2}$-Four shoot training and 10 fruits retained plant $^{-1}, \operatorname{Tr}_{3} \mathrm{FL}_{3}$-Four shoot training and 12 fruits retained plant ${ }^{-1}, \mathrm{Tr}_{4} \mathrm{FL}_{4}{ }^{-}$ Four shoot training and 14 fruits retained plant $^{-1}$ ) were used in the study.

On plot basis, observations recorded were plant height $(\mathrm{cm})$ taken at the end of crop season before start of leaf senescence, ripe fruit weight $(\mathrm{g})$, ripe fruit length $(\mathrm{cm})$, ripe fruit width $(\mathrm{cm})$, harvest durations (days), seed yield plant $^{-1}$ (g) and number of seeds fruit $^{-1}$, determined on freshly harvested fruits from the healthy plant. Three replications were used in each case. 1000 seed weight $(\mathrm{g})$, germination percentage, speed of germination, seed vigour index-I, Seed vigour index-II and electrical conductivity $\left(\mathrm{dsm}^{-1}\right)$ were determined after drying the seed to moisture content of $<8 \%$ as per the ISTA guidelines (3). In case of laboratory 
experiment, 400 seeds in the form of four replications were used for each treatment. Germination was calculated by using the formula:

Germination (\%) $=\frac{\text { Number of normal seedlings }}{\text { Total number of seeds used }} \times 100$

Speed of germination was calculated as:

Speed of Germination $=\frac{X_{1}}{Y_{1}}+\frac{X_{2}-X_{1}}{Y_{2}}+\ldots \ldots \ldots \frac{X_{n}-X_{n-1}}{Y_{n}}$

where, $X_{1}, X_{2}$ and $X_{n}$ are number of seeds germinated on first, second and $n^{\text {th }}$ day, respectively and $Y_{1}, Y_{2}$ and $Y_{n}$ are number of days from sowing to first, second and $\mathrm{n}^{\text {th }}$ count, respectively. Speed of germination was measured by using top of the paper method.

Seedling vigour index-I was calculated as per the formula given by Abdul-Baki and Anderson (1973) (1) as:

Seedling vigour index-I = Germination $(\%) \times$ Seedling length $(\mathrm{cm})$

Seedling vigour index-II was calculated as per the formula given by Abdul-Baki and Anderson (1973) (1) as:

Seedling vigour index-II = Germination $(\%) \mathrm{x}$ Seedling dry weight (mg)

Statistical analysis was done as per experimental design suggested by Panse and Sukhatme, 2000 (17).

\section{Results and Discussion}

\section{Fruit and seed yield parameters}

The data pertaining to the effect of training systems and fruit load on fruit and seed yield parameters have been presented in Tables1 and 2. Significantly maximum plant height
$(63.99 \mathrm{~cm})$ recorded in $\operatorname{Tr}_{2}$ (two stem training system) might be due to the reason that removal of branches enhanced the apical dominance with great competition for space and light that forced the plants to grow taller. The lowest plant height $(51.15 \mathrm{~cm})$ recorded in $\operatorname{Tr}_{3}$ (four stem training system) was statistically at par with $\operatorname{Tr}_{1}$ (no training). These findings are in line with Udit and Girish, 2014 (22) and Singh and Kaur, 2017 (18) in bell pepper. Effects of fruit load and interaction were found to be non-significant. Highest significant ripe fruit weight $(59.04 \mathrm{~g})$ was obtained in $\operatorname{Tr}_{2}$ (two stem training system) and $\operatorname{Tr}_{1}$ (no training) resulted in lowest fruit weight $(52.26 \mathrm{~g})$. The reason for maximum fruit weight could be that pruning treatment resulted in increased fruit weight owing to more production of photosynthates due to better interception of solar radiation resulting in adequate supply of metabolites to limited number of fruits. These findings match with the work done by Shukla et al., 2011 (19) in bell pepper. With regard to fruit load, significantly maximum fruit weight $(62.47 \mathrm{~g})$ was obtained in $\mathrm{FL}_{2}$ (ten fruits plant ${ }^{-}$ $\left.{ }^{1}\right)$ and lowest fruit weight (48.62 g) was obtained in $\mathrm{FL}_{1}$ (retaining of all fruits). These results are in line with the findings of Manjunatha et al., 2007 (12) in bell pepper. In case of interaction effect, significantly maximum ripe fruit weight $(66.65 \mathrm{~g})$ was recorded in the treatment $\mathrm{Tr}_{2} \mathrm{FL}_{2}$ (two stem training with retaining of ten fruits plant ${ }^{-1}$ ) and $\operatorname{Tr}_{1} \mathrm{FL}_{1}$ (no training and retaining all fruits) produced minimum ripe fruit weight $(46.44 \mathrm{~g})$. These results are in agreement with Chen-You, 2000 (6). Training system $\operatorname{Tr}_{2}$ (two stems plant ${ }^{-1}$ ) resulted in significantly maximum fruit length $(6.12 \mathrm{~cm})$ whereas minimum $\left(5.32 \mathrm{~cm}\right.$ ) was recorded in $\operatorname{Tr}_{1}$ (no training). Similar results were observed by Lal, 2013 (8) in bell pepper. For fruit load, maximum significant value $(6.05 \mathrm{~cm})$ was noticed in treatment $\mathrm{FL}_{2}$ (ten fruits plant ${ }^{-1}$ ) whereas minimum fruit length $(5.45 \mathrm{~cm})$ 
recorded in $\mathrm{FL}_{4}$ (14 fruits plant ${ }^{-1}$ ) was statistically at par with $\mathrm{FL}_{1}$ (all fruits retained). These observations are in conformity with Bhatt and Srinivasa Rao, 1997 (4) and Manjunantha et al., 2007 (12) in bell pepper. For interaction effect, maximum fruit length $(6.56 \mathrm{~cm})$ was found in treatment combination $\mathrm{Tr}_{2} \mathrm{FL}_{2}$ whereas minimum value $\left(5.00 \mathrm{~cm}\right.$ ) was recorded in $\operatorname{Tr}_{1} \mathrm{FL}_{1}$ (no training and retaining and all fruits) but with nonsignificant differences. The reason for maximum fruit length in $\mathrm{Tr}_{2} \mathrm{FL}_{2}$ might be due to higher source to sink ratio as in case of more sink, the accumulation of assimilates was low and it directly affected the length of fruit. Significantly maximum fruit width (4.74 $\mathrm{cm}$ ) was observed in $\operatorname{Tr}_{2}$ (two stem) and minimum $(4.15 \mathrm{~cm})$ obtained in $\operatorname{Tr}_{1}$ (no training) was statistically at par with $\operatorname{Tr}_{3}$ (four stem training). Shukla et al., 2011 (19) and Lal, 2013 (8) in capsicum also recorded similar observations. Maximum fruit width $(4.61 \mathrm{~cm})$ was attained in $\mathrm{FL}_{2}$ (retaining of ten fruits plant ${ }^{-1}$ ) (Manjunantha et al., 2007) (12) whereas minimum $(4.18 \mathrm{~cm})$ was recorded in $\mathrm{FL}_{4}$ (retaining of 14 fruits plant ${ }^{-1}$ ) with nonsignificant differences with $\mathrm{FL}_{1}$ (all fruits plant ${ }^{-1}$ ) and $\mathrm{FL}_{3}$ (retaining of twelve fruits plant $\left.^{-1}\right)$.

Table.1 Effect of training system and fruit load on seed on different fruit parameters

\begin{tabular}{|c|c|c|c|c|}
\hline \multirow[b]{2}{*}{ Particulars } & \multicolumn{3}{|c|}{ Characters } & \multirow[b]{2}{*}{$\begin{array}{l}\text { Ripe fruit } \\
\text { width }(\mathrm{cm})\end{array}$} \\
\hline & $\begin{array}{c}\text { Plant Height } \\
(\mathbf{c m})\end{array}$ & $\begin{array}{l}\text { Ripe fruit } \\
\text { weight (g) }\end{array}$ & $\begin{array}{l}\text { Ripe fruit } \\
\text { length }(\mathrm{cm})\end{array}$ & \\
\hline \multicolumn{5}{|c|}{ Main Effect (Training systems) } \\
\hline $\mathbf{T r}_{1}$ & 52.97 & 52.26 & 5.32 & 4.15 \\
\hline $\mathbf{T r}_{2}$ & 63.99 & 59.04 & 6.12 & 4.74 \\
\hline $\mathbf{T r}_{3}$ & 51.15 & 54.74 & 5.63 & 4.22 \\
\hline CD at $5 \%$ & 8.71 & 0.96 & 0.21 & 0.17 \\
\hline \multicolumn{5}{|c|}{ Main Effect (Fruit load) } \\
\hline $\mathbf{F L}_{1}$ & 55.91 & 48.62 & 5.51 & 4.32 \\
\hline $\mathbf{F L}_{2}$ & 58.28 & 62.47 & 6.05 & 4.61 \\
\hline $\mathbf{F L}_{3}$ & 56.07 & 57.31 & 5.76 & 4.37 \\
\hline $\mathbf{F L}_{4}$ & 53.91 & 52.98 & 5.45 & 4.18 \\
\hline CD at $5 \%$ & NS & 1.10 & 0.24 & 0.19 \\
\hline \multicolumn{5}{|c|}{ Interaction (Training system x Fruit load) } \\
\hline $\operatorname{Tr}_{1} \mathbf{F L}_{1}$ & 52.90 & 46.44 & 5.00 & 3.77 \\
\hline $\mathbf{T r}_{1} \mathbf{F L}_{2}$ & 51.66 & 57.23 & 5.61 & 4.57 \\
\hline $\operatorname{Tr}_{1} \mathbf{F L}_{3}$ & 48.05 & 53.80 & 5.45 & 4.25 \\
\hline $\mathbf{T r}_{1} \mathrm{FL}_{4}$ & 59.29 & 51.57 & 5.24 & 4.02 \\
\hline $\operatorname{Tr}_{2} \mathbf{F L}_{1}$ & 66.99 & 50.89 & 5.97 & 4.81 \\
\hline $\operatorname{Tr}_{2} \mathbf{F L}_{2}$ & 67.53 & 66.65 & 6.56 & 5.05 \\
\hline $\mathbf{T r}_{2} \mathbf{F L}_{3}$ & 60.89 & 62.62 & 6.22 & 4.75 \\
\hline $\operatorname{Tr}_{2} \mathbf{F L}_{4}$ & 60.59 & 56.02 & 5.77 & 4.36 \\
\hline $\operatorname{Tr}_{3} F L_{1}$ & 47.84 & 48.55 & 5.58 & 4.40 \\
\hline $\operatorname{Tr}_{3} \mathbf{F L}_{2}$ & 55.65 & 63.53 & 5.99 & 4.22 \\
\hline $\operatorname{Tr}_{3} F_{3}$ & 59.27 & 55.51 & 5.60 & 4.11 \\
\hline $\mathbf{T r}_{3} \mathbf{F L}_{4}$ & 41.85 & 51.36 & 5.36 & 4.16 \\
\hline CD at $5 \%$ & NS & 1.91 & NS & 0.34 \\
\hline
\end{tabular}


Table.2 Effect of training system and fruit load on harvest duration and seed yield parameters

\begin{tabular}{|c|c|c|c|}
\hline \multirow[b]{2}{*}{ Particulars } & \multicolumn{3}{|c|}{ Characters } \\
\hline & $\begin{array}{c}\text { Harvest } \\
\text { duration } \\
\text { (days) }\end{array}$ & $\begin{array}{c}\text { Seed yield plant } \\
(\mathrm{g})\end{array}$ & $\begin{array}{c}\text { Number of seeds } \\
\text { fruit }^{-1}\end{array}$ \\
\hline \multicolumn{4}{|c|}{ Main Effect (Training systems) } \\
\hline $\mathbf{T r}_{1}$ & 81.92 & 8.78 & 159.62 \\
\hline $\mathbf{T r}_{2}$ & 78.25 & 8.67 & 172.22 \\
\hline $\mathbf{T r}_{3}$ & 78.42 & 8.24 & 164.38 \\
\hline CD at $5 \%$ & 2.73 & 0.45 & 3.33 \\
\hline \multicolumn{4}{|c|}{ Main Effect (Fruit load) } \\
\hline $\mathbf{F L}_{1}$ & 82.44 & 9.16 & 158.81 \\
\hline $\mathbf{F L}_{2}$ & 76.89 & 8.43 & 174.51 \\
\hline $\mathbf{F L}_{3}$ & 79.22 & 8.27 & 166.52 \\
\hline $\mathbf{F L}_{4}$ & 79.56 & 8.40 & 161.79 \\
\hline CD at $5 \%$ & 3.15 & 0.52 & 3.84 \\
\hline \multicolumn{4}{|c|}{ Interaction (Training system x Fruit load) } \\
\hline $\mathbf{T r}_{1} \mathbf{F L}_{1}$ & 85.00 & 10.34 & 154.03 \\
\hline $\operatorname{Tr}_{1} F L_{2}$ & 78.66 & 8.26 & 165.43 \\
\hline $\operatorname{Tr}_{1} \mathrm{FL}_{3}$ & 81.32 & 8.21 & 161.20 \\
\hline $\operatorname{Tr}_{1} \mathbf{F L}_{4}$ & 82.68 & 8.34 & 157.80 \\
\hline $\operatorname{Tr}_{2} \mathbf{F L}_{1}$ & 80.30 & 8.40 & 161.80 \\
\hline $\operatorname{Tr}_{2} F_{2}$ & 75.67 & 9.16 & 187.77 \\
\hline $\operatorname{Tr}_{2} \mathbf{F L} L_{3}$ & 77.69 & 8.52 & 171.80 \\
\hline $\operatorname{Tr}_{2} \mathrm{FL}_{4}$ & 79.32 & 8.58 & 167.53 \\
\hline $\operatorname{Tr}_{3} F_{1}$ & 82.00 & 8.73 & 160.60 \\
\hline $\operatorname{Tr}_{3} F L_{2}$ & 76.31 & 7.88 & 170.33 \\
\hline $\operatorname{Tr}_{3} F L_{3}$ & 78.64 & 8.07 & 166.58 \\
\hline $\operatorname{Tr}_{3} \mathbf{F L}_{4}$ & 76.67 & 8.27 & 160.03 \\
\hline CD at $5 \%$ & NS & 0.90 & 6.66 \\
\hline
\end{tabular}


Table.3 Effect of training system and fruit load on different seed parameters

\begin{tabular}{|c|c|c|c|}
\hline \multirow[b]{2}{*}{ Particulars } & \multicolumn{3}{|c|}{ Characters } \\
\hline & $\begin{array}{l}1000 \text { seed } \\
\text { weight }(g)\end{array}$ & Germination \% & $\begin{array}{c}\text { Speed of } \\
\text { germination }\end{array}$ \\
\hline \multicolumn{4}{|c|}{ Main Effect (Training systems) } \\
\hline $\mathbf{T r}_{1}$ & 5.58 & $84.18(9.23)$ & 9.40 \\
\hline $\mathbf{T r}_{2}$ & 5.90 & $91.25(9.60)$ & 12.31 \\
\hline $\mathbf{T r}_{3}$ & 5.70 & $88.18(9.43)$ & 10.42 \\
\hline CD at $5 \%$ & 0.06 & 0.04 & 0.47 \\
\hline \multicolumn{4}{|c|}{ Main Effect (Fruit load) } \\
\hline $\mathbf{F L}_{1}$ & 5.61 & $82.16(9.12)$ & 9.13 \\
\hline $\mathbf{F L}_{2}$ & 5.86 & $92.16(9.65)$ & 12.74 \\
\hline $\mathbf{F L}_{3}$ & 5.77 & $90.33(9.55)$ & 10.81 \\
\hline $\mathbf{F L}_{4}$ & 5.68 & $86.78(9.37)$ & 10.18 \\
\hline CD at $5 \%$ & 0.07 & 0.05 & 0.55 \\
\hline \multicolumn{4}{|c|}{ Interaction (Training system $x$ Fruit load) } \\
\hline $\operatorname{Tr}_{1} \mathbf{F L}_{1}$ & 5.53 & $81.75(9.09)$ & 7.72 \\
\hline $\operatorname{Tr}_{1} \mathbf{F L}_{2}$ & 5.63 & $88.00(9.43)$ & 10.75 \\
\hline $\operatorname{Tr}_{1} \mathbf{F L}_{3}$ & 5.62 & $85.00(9.27)$ & 10.03 \\
\hline $\mathrm{Tr}_{1} \mathrm{FL}_{4}$ & 5.54 & $82.00(9.11)$ & 9.16 \\
\hline $\operatorname{Tr}_{2} \mathbf{F L} \mathbf{L}_{1}$ & 5.63 & $82.75(9.15)$ & 9.88 \\
\hline $\operatorname{Tr}_{2} \mathbf{F L}_{2}$ & 6.21 & $96.50(9.88)$ & 15.95 \\
\hline $\mathbf{T r}_{2} \mathbf{F L}_{3}$ & 6.00 & $94.00(9.75)$ & 12.38 \\
\hline $\operatorname{Tr}_{2} \mathbf{F L}_{4}$ & 5.78 & $91.75(9.63)$ & 11.03 \\
\hline $\operatorname{Tr}_{3} F_{1}$ & 5.66 & $82.00(9.11)$ & 9.80 \\
\hline $\operatorname{Tr}_{3} F_{2}$ & 5.73 & $92.00(9.64)$ & 11.52 \\
\hline $\operatorname{Tr}_{3} F_{3}$ & 5.68 & $92.00(9.64)$ & 10.01 \\
\hline $\mathrm{Tr}_{3} \mathrm{FL}_{4}$ & 5.70 & $86.75(9.36)$ & 10.36 \\
\hline CD at $5 \%$ & 0.12 & 0.05 & 0.95 \\
\hline
\end{tabular}


Table.4 Effect of training system and fruit load on different seed parameters

\begin{tabular}{|c|c|c|c|}
\hline \multirow[b]{2}{*}{ Particulars } & \multicolumn{3}{|c|}{ Characters } \\
\hline & SV-I & SV-II & $\begin{array}{c}\text { Electrical } \\
\text { conductivity } \\
\left(\mathrm{dSm}^{-1}\right)\end{array}$ \\
\hline \multicolumn{4}{|c|}{ Main Effect (Training systems) } \\
\hline $\mathbf{T r}_{1}$ & 747.39 & 202.48 & 0.123 \\
\hline $\mathbf{T r}_{2}$ & 1066.05 & 243.90 & 0.090 \\
\hline $\mathbf{T r}_{3}$ & 926.45 & 221.54 & 0.106 \\
\hline CD at $5 \%$ & 53.54 & 3.43 & 0.008 \\
\hline \multicolumn{4}{|c|}{ Main Effect (Fruit load) } \\
\hline $\mathbf{F L}_{1}$ & 757.05 & 187.93 & 0.117 \\
\hline $\mathbf{F L}_{2}$ & 1112.29 & 257.09 & 0.082 \\
\hline $\mathbf{F L}_{3}$ & 928.27 & 233.86 & 0.112 \\
\hline $\mathbf{F L}_{4}$ & 855.57 & 211.67 & 0.114 \\
\hline CD at $5 \%$ & 61.82 & 4.54 & 0.009 \\
\hline \multicolumn{4}{|c|}{ Interaction (Training system $x$ Fruit load) } \\
\hline $\operatorname{Tr}_{1} \mathbf{F L}_{1}$ & 664.56 & 173.13 & 0.120 \\
\hline $\operatorname{Tr}_{1} F_{2}$ & 823.42 & 231.98 & 0.121 \\
\hline $\mathbf{T r}_{1} \mathbf{F L}_{3}$ & 774.20 & 208.40 & 0.127 \\
\hline $\operatorname{Tr}_{1} \mathrm{FL}_{4}$ & 727.37 & 196.39 & 0.126 \\
\hline $\mathbf{T r}_{2} \mathbf{F L}_{1}$ & 846.95 & 199.14 & 0.103 \\
\hline $\mathbf{T r}_{2} \mathbf{F L}_{2}$ & 1448.30 & 284.77 & 0.060 \\
\hline $\mathrm{Tr}_{2} \mathrm{FL}_{3}$ & 1021.56 & 253.79 & 0.100 \\
\hline $\operatorname{Tr}_{2} \mathrm{FL}_{4}$ & 947.38 & 237.90 & 0.097 \\
\hline $\operatorname{Tr}_{3} F_{1}$ & 759.64 & 191.52 & 0.127 \\
\hline $\mathrm{Tr}_{3} \mathrm{FL}_{2}$ & 1065.14 & 254.51 & 0.067 \\
\hline $\mathrm{Tr}_{3} \mathrm{FL}_{3}$ & 989.06 & 239.39 & 0.110 \\
\hline $\operatorname{Tr}_{3} F_{4}$ & 891.97 & 200.72 & 0.120 \\
\hline CD at $5 \%$ & 107.09 & 7.86 & 0.015 \\
\hline
\end{tabular}

Treatment combination $\mathrm{Tr}_{2} \mathrm{FL}_{2}$ gave significantly maximum fruit width $(5.05 \mathrm{~cm})$ being in conformity with Mitra et al., 2014 (13), however, $\operatorname{Tr}_{1} \mathrm{FL}_{1}$ recorded minimum (3.77) which was statistically at par with $\mathrm{Tr}_{1} \mathrm{FL}_{4}(4.02 \mathrm{~cm})$ and $\mathrm{Tr}_{3} \mathrm{FL}_{3}(4.11 \mathrm{~cm})$. Treatment $\operatorname{Tr}_{1}$ (no training) resulted in significantly better harvest duration (81.92 days). This is in conformity with Onis et al., 2001 (15). In case of fruit load, $\mathrm{FL}_{1}$ (all fruits retained plant $\left.^{-1}\right)$ recorded maximum harvest duration (82.44 days) being statistically at par with $\mathrm{FL}_{4}$ (fourteen fruits retained) while minimum harvest duration (76.89 days) recorded in $\mathrm{FL}_{2}$ (ten fruits plant ${ }^{-1}$ retained) was statistically at par with $\mathrm{FL}_{3}$ (twelve fruits plant $^{-1}$ ) and $\mathrm{FL}_{4}$. This might be due to less fruits plant ${ }^{-1}$ and more carbohydrates stored in two stem training system. The interaction effect for harvest duration was found to be non-significant. Training system $\operatorname{Tr}_{1}$ (no training) recorded maximum significant seed yield plant ${ }^{-1}(8.78 \mathrm{~g})$ which was statistically at par with $\operatorname{Tr}_{2}(8.67 \mathrm{~g})$ and minimum seed yield 
plant ${ }^{-1}\left(8.24 \mathrm{~g}\right.$ ) obtained in $\operatorname{Tr}_{3}$ (four stem training system) was statistically at par with $\operatorname{Tr}_{2}$. This might be due to fact that $\operatorname{Tr}_{1}$ had more number of branches which produced more number of fruits plant ${ }^{-1}$ resulting in higher seed yield. Retaining all fruits on a plant $\left(\mathrm{FL}_{1}\right)$ resulted in significantly maximum seed yield plant $^{-1}(9.16 \mathrm{~g})$ whereas minimum $(8.27 \mathrm{~g})$ recorded in $\mathrm{FL}_{3}$ (twelve fruits plant ${ }^{-1}$ ) was statistically at par with $\mathrm{FL}_{2}(8.43 \mathrm{~g})$ and $\mathrm{FL}_{4}(8.40 \mathrm{~g})$. Treatment combination $\mathrm{Tr}_{1} \mathrm{FL}_{1}$ showed significantly maximum seed yield plant $^{-1}(10.34 \mathrm{~g})$ and minimum $(7.88 \mathrm{~g})$ observed in $\operatorname{Tr}_{3} \mathrm{FL}_{2}$ was statistically at par with $\operatorname{Tr}_{2} \mathrm{FL}_{1}, \mathrm{Tr}_{3} \mathrm{FL}_{3}, \mathrm{Tr}_{1} \mathrm{FL}_{2}, \mathrm{Tr}_{1} \mathrm{FL}_{3}, \mathrm{Tr}_{2} \mathrm{FL}_{3}$, $\mathrm{Tr}_{3} \mathrm{FL}_{1}, \quad \mathrm{Tr}_{1} \mathrm{FL}_{4}, \quad \mathrm{Tr}_{2} \mathrm{FL}_{4}$ and $\mathrm{Tr}_{3} \mathrm{FL}_{4}$. Significantly maximum number of seeds fruit 1 (172.22) observed in $\operatorname{Tr}_{2}$ is in line with Osman and George, 1984 (16) and the minimum (159.62) was noticed in case of $\operatorname{Tr}_{1}$ (no training). Significantly highest seed number (174.51) was found in $\mathrm{FL}_{2}$ (ten fruits retained plant $^{-1}$ ) being in conformity with Manjunantha et al., 2007 (12) in bell pepper. Minimum seed number (158.81) was observed in $\mathrm{FL}_{1}$ (all fruits retained), being statistically at par with $\mathrm{FL}_{4}$ (161.79).

In case of interaction, significantly maximum number of seeds fruit ${ }^{-1}$ in $\operatorname{Tr}_{2} \mathrm{FL}_{2}$ (187.77) might be due to large size of fruit with reduced sink load. $\operatorname{Tr}_{1} \mathrm{FL}_{1}$ resulted in minimum number of seeds fruit ${ }^{-1}$ (154.03), which was statistically at par with $\operatorname{Tr}_{1} \mathrm{FL}_{4}$ (157.80), $\quad \operatorname{Tr}_{3} \mathrm{FL}_{1}$ (160.60) and $\mathrm{Tr}_{3} \mathrm{FL}_{4}$ (160.03).

\section{Seed quality parameters}

The data pertaining to the effect of training system and fruit load on different seed quality parameters have been presented in Tables 3 and 4. Training system $\operatorname{Tr}_{2}$ (two stem training system) recorded significantly highest 1000 seed weight $(5.90 \mathrm{~g})$ whereas training $\operatorname{Tr}_{1}$ (no training) resulted in the lowest 1000 seed weight $(5.58 \mathrm{~g})$. These studies are in agreement with and Lal et al., 2016 (9) in capsicum. For fruit load, significantly maximum 1000 seed weight $(5.86 \mathrm{~g})$ was observed in $\mathrm{FL}_{2}$ (ten fruits plant ${ }^{-1}$ retained) and minimum 1000 seed weight (5.61 g) recorded in $\mathrm{FL}_{1}$ (retaining all fruits plant ${ }^{-1}$ ) was statistically at par with $\mathrm{FL}_{4}$ (5.68). This might be due to the fact that removal of flowers from bell pepper increased the concentrations of stored carbohydrates in stems making them available to developing seeds. Significantly maximum 1000 seed weight $(6.21 \mathrm{~g})$ was noticed in $\mathrm{Tr}_{2} \mathrm{FL}_{2}$ whereas minimum 1000 seed weight (5.53 g) obtained in $\operatorname{Tr}_{1} \mathrm{FL}_{1}$ was statistically at par with $\operatorname{Tr}_{1} \mathrm{FL}_{2}$, $\operatorname{Tr}_{1} \mathrm{FL}_{3}, \operatorname{Tr}_{1} \mathrm{FL}_{4}$ and $\mathrm{Tr}_{2} \mathrm{FL}_{1}$. $\mathrm{Tr}_{2}$ (two stem training system) resulted significantly higher germination $(91.25 \%)$ being in line with Ansari, 2012 (2) in tomato and Lal, 2013 (8) in bell pepper, however, $\operatorname{Tr}_{1}$ (no training) lead to minimum germination $(84.18 \%)$. This might be due to more partitioning of carbohydrates to different stems. $\mathrm{FL}_{2}$ (ten fruits plant $^{-1}$ ) recorded maximum seed germination $\left(92.16 \%\right.$ ) and $\mathrm{FL}_{1}$ (all fruits) had minimum seed germination (82.16\%) (14). Significantly higher germination $(96.50 \%)$ noticed in $\mathrm{Tr}_{2} \mathrm{FL}_{2}$ might be due to less branches and fruits that lead to more photosynthates availability to developing fruits and seeds which can be correlated to higher seed germination. Minimum germination $(81.75 \%)$ observed in $\mathrm{Tr}_{1} \mathrm{FL}_{1}$ was statistically at par with $\mathrm{Tr}_{1} \mathrm{FL}_{4}, \mathrm{Tr}_{2} \mathrm{FL}_{1}$ and $\mathrm{Tr}_{3} \mathrm{FL}_{1}$. Training system $\mathrm{Tr}_{2}$ (two stem) recorded significantly maximum speed of germination (12.31) while minimum speed of germination (9.40) was obtained in $\operatorname{Tr}_{1}$ (no training). This is because of its correlation with high germination in two stem training system. As far as fruit load is concerned, $\mathrm{FL}_{2}$ (ten fruits plant $^{-1}$ ) showed significantly maximum speed of germination (12.74) (20) and $\mathrm{FL}_{1}$ (all fruits retained plant $^{-1}$ ) had minimum speed of germination (9.13). 
Among the interactions, treatment combination $\operatorname{Tr}_{2} \mathrm{FL}_{2}$ produced significantly maximum speed of germination (15.95), however, $\operatorname{Tr}_{1} \mathrm{FL}_{1}$ resulted in minimum speed of germination (7.72). Significantly maximum seed vigour index-I (1066.05) was obtained in $\mathrm{Tr}_{2}$ (two stem) whereas minimum (747.39) was observed in $\operatorname{Tr}_{1}$ (no training). Maximum SVI-I in $\operatorname{Tr}_{2}$ could be due to the fact that two stems plant ${ }^{-1}$ had less number of fruits and there was less competition among the fruits for photosynthates, thereby resulting in bigger sized fruits with bolder seeds (8). In case of fruit load, maximum SVI-I (1112.9) was recorded in $\mathrm{FL}_{2}$ (ten fruits plant ${ }^{-1}$ ) whereas the minimum SVI-I (757.05) was obtained in $\mathrm{FL}_{1}$ (all fruits retained). Amongst interactions, $\mathrm{Tr}_{2} \mathrm{FL}_{2}$ resulted in significantly maximum SVI-I (1448.30) while minimum SVI-I (664.56) observed in $\operatorname{Tr}_{1} \mathrm{FL}_{1}$ had statistical similarity with $\operatorname{Tr}_{1} \mathrm{FL}_{4}$ and $\operatorname{Tr}_{3} \mathrm{FL}_{1}$. Seed vigour index-II was significantly maximum (243.90) in $\operatorname{Tr}_{2}$ (two stem training system) and minimum (202.48) in $\operatorname{Tr}_{1}$ (no training).

For fruit load, significantly maximum SVI-II (257.09) was found in $\mathrm{FL}_{2}$ (ten fruits plant ${ }^{-1}$ ) and minimum (187.93) was observed in $\mathrm{FL}_{1}$ (all fruits plant ${ }^{-1}$ ). Interaction $\mathrm{Tr}_{2} \mathrm{FL}_{2}$ recorded significantly maximum SVI-II (284.77) and minimum (173.13) was obtained in $\operatorname{Tr}_{1} \mathrm{FL}_{1}$. Two stem training system $\left(\mathrm{Tr}_{2}\right)$ registered significantly minimum EC $(0.090$ $\mathrm{dSm}{ }^{-1}$ ) whereas in case of $\operatorname{Tr}_{1}$ (no training at all), it was maximum EC $\left(0.123 \mathrm{dSm}^{-1}\right)$. This might be due to more partitioning of photosynthates in case of no training. On the other hand, fruit load $\mathrm{FL}_{2}$ (ten fruits) recorded significantly minimum EC $\left(0.082 \mathrm{dSm}^{-1}\right)$ which has conformity with Vasudevan et al., 2008 (23) in methi and Lakshmi et al., 2015 (10) in fenugreek. Fruit load $\mathrm{FL}_{1}$ (all fruits) had maximum EC $\left(0.117 \mathrm{dSm}^{-1}\right)$ being statistically at par with $\mathrm{FL}_{4}$ and $\mathrm{FL}_{3}$. Interaction $\mathrm{Tr}_{2} \mathrm{FL}_{2}$ had minimum EC (0.060 $\mathrm{dSm}^{-1}$ ) of seed being statistically at par with
$\operatorname{Tr}_{3} \mathrm{FL}_{2}$. This might be due to effective translocation of phtotosythates from source to sink which is evident from high seed weight, high germination (\%), high dry weight and more seed vigour index. The maximum EC $\left(0.127 \mathrm{dS} \mathrm{m}^{-1}\right.$ ) observed in case of $\mathrm{Tr}_{1} \mathrm{FL}_{3}$ (no training and twelve fruits plant ${ }^{-1}$ ) and $\mathrm{Tr}_{3} \mathrm{FL}_{1}$ was statistically at par with, $\mathrm{Tr}_{1} \mathrm{FL}_{4}$, $\operatorname{Tr}_{1} \mathrm{FL}_{2}, \operatorname{Tr}_{1} \mathrm{FL}_{1}$ and $\mathrm{Tr}_{3} \mathrm{FL}_{4}$.

\section{Acknowledgment}

The authors are thankful to the Professor and Head, Department of Seed Science \& Technology, YSP University of Horticulture and Forestry, Nauni (Solan), India for providing necessary guidance and facilities during the course of investigations.

\section{References}

1.Abdul-Baki AA \& Anderson JD.1973. Vigour determination in soyabean seed by multiple criteria. Crop Science 13:630-633.

2.Ansari G. 2012. Studies on effect of planting density and training system on seed production in tomato (Solanum lycopersicum L.). M.Sc. Thesis, Dr. Y.S. Parmar University of Horticulture and Forestry, Nauni, Solan. 68p.

3.Anonymous.1985. ISTA (International Seed Testing Association). International rules for seed testing. Seed Science and Technology 13:300-520.

4.Bhatt RM and Srinivasa Rao NK. 1997. Growth and photosynthesis in bell pepper as affected by sink manipulation. Biologia Plantarum 39:437-439.

5.Bukasov SM. 1930. The cultivated plants of Mexico, Guatemala and Columbia. Bulletin of Applied Botanical Genetics and Plant Breeding Supplement 47:261-273.

6.Chen-YouYuan. 2000. Effects of different training methods on yield and quality of some netted melon varieties in soilless culture. Acta Agriculturae Shanghai 16:60-64.

7.Greenleaf WH. 1986. Pepper Breeding. In: Breeding Vegetable Crops. (MJ Bassett ed.), AVI, West port. pp. 67-134.

8.Lal M. 2013. Studies on planting density and 
training on seed production of bell pepper (capsicum annuum L.) under protected conditions. M.Sc. Thesis, Dr. Y.S. Parmar University of Horticulture and Forestry, Nauni, Solan. 74p.

9.Lal M, Kanwar HS, Kanwar R and Negi C. 2016. Effect of planting density and training on plant health and seed quality of bell pepper (Capsicum annuum L.) under protected conditions. Journal of Applied and Natural Science 8:1219-1222.

10.Lakshmi J, Gowada R, Parashivmurty M, Narayanaswamy S and Shivanandam. 2015. Influence of pre flowering pinching and maleic hydrazide spray on plant growth, seed yield and quality attributes in fenugreek. Legume Research-An International Journal 38: 353357.

11.Maboko MM, Du Plooy CP and Chiloane S. 2011. Effect of plant population, fruit and stem pruning on yield and quality of hydroponically grown tomato. African Journal of Agricultural Research 6:5144-5148.

12.Manjunatha KC, Yogeesha HS, Rame G, Prasanna KPR. 2007. Influence of fruit load on seed yield and quality in bell pepper (Capsicum annuum L.). Seed-Research 35:238-239.

13.Mitra S, Sarker K, Alam MS, Islam S and Rabbani MG. 2014. Effects of stem pruning and fruit thinning on yield components and yield of tomato. Bangladesh Journal of Progressive Science and Technology 12:101104. O

14.Nabi A, Sharma SK, Shukla YR. 2009. Effect of fruit load on seed yield and quality of okra. Annals of Biology 25:147-149.

15.Onis A, Lopez Camelo A and Gomez P. 2001. Effect of pruning to two and four branches on bell peppers production in a non heated greenhouse. Revista de la Facultey de Agrnomia Universidad de Buenos Aires 21:511.
16.Osman OA and George RAT. 1984. The effect of mineral nutrition and fruit position on seed yield and quality in sweet pepper (Capsicum annuum L.). Acta Horticulturae 143:133-141.

17.Panse VG and Sukhatme PV. 2000. Statistical Methods for Agricultural Workers. ICAR, New Delhi 345p.

18.Singh I and Kaur A. 2017. Effect of pruning systems on growth and yield traits of greenhouse grown bell pepper (Capsicum annuum L. var. grossum). Indian Journal of Agricultural Research 52:414-418.

19.Shukla YR, Sharma D and Upasna T. 2011. Studies on training systems and NAA application on bell pepper production in polyhouse. Journal of Horticultural Science 6:59-61.

20.Tabasi A, Nemati H, Tehranifar A and Akbari M. 2011. The effects of shrub pruning and fruit thinning on seed germination and seedling of tomato in the next generation (Lycopersicon esculentum Mill). Journal of Biological and Environment Science 5:105110.

21.Thakur G, Singh AK, Patel P, Maurya PK and Kumar U. 2018. Effect of training level on growth and yield of capsicum (Capsicum annuum L) hybrid buffalo under natural ventilated polyhouse. Journal of Pharmacognosy and Phytochemistry SP1:8285.

22.Udish K and Girish C. 2014. Effect of spacing and training level on growth and yield of capsicum under polyhouse in North-Bihar condition. Journal of Hill Agriculture 5:9-12.

23. Vasudevan SN, Sudarshan JS, Kurdikeri MB and Dharmatti PR. 2008. Influence of pinching of apical bud and chemical sprays on seed yield and quality of fenugreek. Karnataka Journal of Agricultural Sciences 21:26-29.

\section{How to cite this article:}

Rohit Chandi, Rajender Sharma and Shukla, Y. R. 2020. Effect of Training System and Fruit Load on Seed Production and Quality of Bell Pepper. Int.J.Curr.Microbiol.App.Sci. 9(07): 2420-2429. doi: https://doi.org/10.20546/ijcmas.2020.907.284 